NOTE

\title{
Overwintering by trilobite larvae of the horseshoe crab Limulus polyphemus on a sandy beach of Delaware Bay (New Jersey, USA)
}

\author{
Mark L. Botton ${ }^{1, *}$, Robert E. Loveland ${ }^{2}$, Timothy R. Jacobsen ${ }^{3}$ \\ 'Division of Science and Mathematics, Fordham University, College at Lincoln Center, New York, New York 10023, USA \\ ${ }^{2}$ Department of Biological Sciences and Bureau of Biological Research, Rutgers - The State University, Nelson Biological Laboratories, \\ Piscataway, New Jersey 08854, USA \\ ${ }^{3}$ Cumberland County College, PO Box 517, Vineland, New Jersey 08360, USA
}

\begin{abstract}
Trilobite larvae of the horseshoe crab Limulus polyphemus L. develop from eggs deposited within intertidal sediments. Most of these larvae emerge from sediments during the summer. We have found that a smaller component of the larval population on a Delaware Bay (New Jersey, USA) beach can delay emergence, and remain alive within the sediments until the following spring. Overwintering trilobites were distributed in a $3 \mathrm{~m}$ wide band in the mid-tide region, at sediment depths $>15 \mathrm{~cm} \cdot 10^{3}$ to $10^{4}$ live trilobites $\mathrm{m}^{-2}$ have been found throughout winter and into early spring. This phenomenon may be ecologically significant, since emergence of overwintering larvae in early spring occurs at a time when predation by birds is minimal. Sediment disturbance by winter storms may be the major factor limiting the survivorship of overwintering cohorts.
\end{abstract}

Adult horseshoe crabs Limulus polyphemus L. deposit eggs within intertidal beaches from Maine, USA, to Yucatan, during spring and early summer (Shuster 1982). A large concentration of spawning $L$. polyphemus occurs in lower Delaware Bay (New Jersey, USA) (Shuster \& Botton 1985, Botton et al. 1988), first appearing in late April. Peak numbers of horseshoe crabs are generally associated with spring high tides during May and June, although a small spawning population persists through July and August (Botton 1984a, Shuster \& Botton 1985). Eggs develop through the larval stage ('trilobite') within the sand. The developmental rate of embryos is temperature dependent (French 1979, Jegla \& Costlow 1982, Sekiguchi 1988), but under typical field conditions in Delaware Bay, trilobites are common within beach sediments 3 to 4 wk after fertilization. Rudloe (1979) found that trilobite emergence was correlated with full moon

\footnotetext{
- Addressee for correspondence
}

or unusually heavy wave action. Within 2 additional weeks, trilobites molt into the benthic first posthatch juvenile stage (Sekiguchi et al. 1988). Based on these findings, one might predict that no trilobite larvae should remain within beach sediments by late summer.

In this paper, we present field evidence that trilobite larvae of Limulus polyphemus overwinter on sandy beaches of Delaware Bay. This previously unknown life-history phenomenon is discussed with respect to the ecology of these beaches and the population biology of this species.

Material and methods. The study area was located near the Rutgers University Shellfish Research Laboratory in Cape May County, New Jersey (cf. Fig. 1 in Botton et al. 1988), an optimal area for horseshoe crab spawning along the western shore of Delaware Bay (Shuster \& Botton 1985). The beach is ca $12 \mathrm{~m}$ wide with a $6^{\circ}$ slope. The beach was sampled at low tide on 33 dates between January 1989 and January 1992 at ca 3 to $4 \mathrm{wk}$ intervals, with the exception of the period from 6 July 1990 to 14 January 1991. Replicate transects were established $1 \mathrm{~m}$ apart on the beach from the spring high water mark to mean low water. Only the mid-beach region is discussed in this paper, because no overwintering trilobites were found above or below this zone. Three stations on the transect, within the midbeach region, were established at $1.5 \mathrm{~m}$ intervals. The exact position of each station was fixed relative to a reference marker located in a vegetated area above the high tide line. Transects were established north or south of this reference marker in order to avoid sampling the same region consecutively. Plots within a station along the transect were $35 \mathrm{~cm}$ on a side (area $0.1225 \mathrm{~m}^{2}$ ). We sequentially excavated $5 \mathrm{~cm}$ slices of 
sediment within the plot frame, from the surface to a maximum depth of 25 or $30 \mathrm{~cm}$. Sand from the entire slice was mixed thoroughly, and a 1 I sediment sample was placed into a plastic bag. Samples were refrigerated $\left(5^{\circ} \mathrm{C}\right)$ for laboratory analysis, which commenced within a few days. In all, 682 samples were taken.

Three separate aliquots of sand (usually $80 \mathrm{ml}$, but occasionally less in samples containing large numbers of eggs) were washed through a $1 \mathrm{~mm}$ mesh. Horseshoe crab eggs, embryos and trilobite larvae, and other macrofauna were counted. To compute trilobite density (expressed as trilobites $\mathrm{m}^{-2}$ ), the average of the aliquots for a particular depth was summed over all depths from surface $(0$ to $5 \mathrm{~cm}$ ) to bottom (down to 25 to $30 \mathrm{~cm}$ ). Densities for replicate transects were averaged for purposes of plotting.

Throughout this study, samples of live trilobite larvae were separated from the sand and maintained in plastic Petri dishes with filtered sea water in order to determine their competency to molt to the first post-hatched juvenile stage.

Results. Overwintering trilobite larvae of Limulus polyphemus were found during 3 of the past 4 winters in Delaware Bay (Fig. 1). In January 1989, live trilobite larvae of the 1988 year class were discovered in beach sediments at depths of 15 to $25 \mathrm{~cm}$. These larvae persisted throughout March, but were absent from the sediments by mid-April 1989. The 1989 year class of horseshoe crab trilobite larvae were first detected in mid-June, ca 1 mo after adult horseshoe crabs were observed to begin their spawning activity on the study beach. By October 1989, there were still over 7000

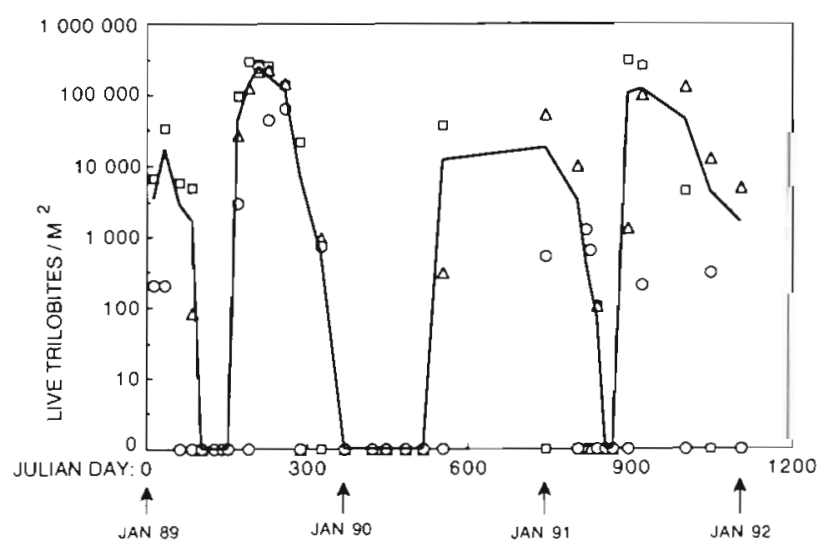

Fig. 1. Limulus polyphemus. No. of live trilobite larvae over time $\left(\log\right.$ live larvae $\left.\mathrm{m}^{-2}\right)$ at the mid-tide region of a Delaware Bay (New Jersey, USA) beach. Stns $6(-), 7.5(\triangle)$, and 9 were located at $6,7.5$, and $9 \mathrm{~m}$ down a transect line beginning at the spring high water line; replicate transects were averaged. The line depicts the average within the entire mid-tide region. Julian day 0 refers to 1 January 1989 . Note that no samples were collected between 6 July 1990 and 14 January 1991 trilobites $m^{-2}$ in the mid-beach region. However, by 22 November, the day after a powerful onshore storm struck the beach, only a few live trilobites remained. Beyond this, however, no live trilobites were detected until the 1990 year class appeared in June 1990. This cohort persisted throughout the fall and into the winter, with average mid-beach densities of 18000 live trilobites $\mathrm{m}^{-2}$ on 14 January 1991, and gradually declined during the winter and early spring 1991. The 1991 year class of trilobites, which first appeared in mid-June 1991, has persisted through January 1992.

During the summer months, live trilobite larvae are occasionally seen in surface sediments $(0$ to $5 \mathrm{~cm})$ but the highest densities are usually encountered in the 10 to $15 \mathrm{~cm}$ and 15 to $20 \mathrm{~cm}$ strata. In contrast, all of the overwintering larvae were found at sediment depths $>15 \mathrm{~cm}$. Live trilobites were extracted from this stratum at temperatures ranging from $1^{\circ} \mathrm{C}$ (March 1989) to $30^{\circ} \mathrm{C}$ (June 1989).

Carapaces of dead trilobite larvae persist in identifiable condition for several months at cold temperatures. We monitored the presence of dead trilobites in order to determine the fate of the overwintering cohorts. The density of dead trilobites parallels that of live trilobites (Fig. 2).

Competency to molt to the first posthatch juvenile stage was exhibited when trilobite larvae, obtained throughout the year, were cultured in filtered room temperature bay water. Overwintering larvae commenced swimming readily under these conditions. Molting to the first posthatch juvenile stage generally took place 10 to $14 \mathrm{~d}$ after the trilobites were sorted from the sediments. No morphological or size differences were apparent when comparing overwintering larvae to normal summer cohorts. Late overwintering larvae had less of the greenish-brown yolk tissue in the hepatopancreas than summer larvae. Preliminary

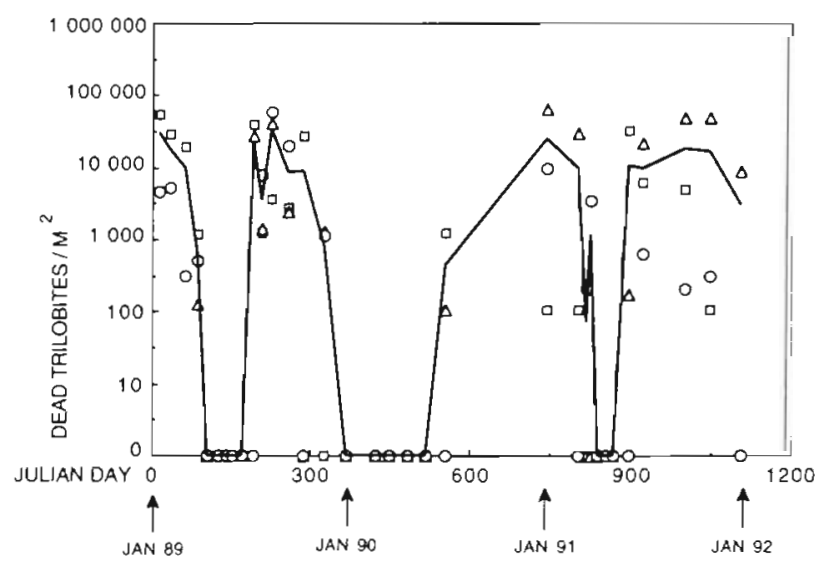

Fig. 2. Limulus polyphemus. As in Fig. 1, except no. of dead trilobite larvae over time 
uptake experiments using labeled bacteria (Chelermwat \& Jacobsen unpubl.) showed that trilobites do not appear capable of obtaining nutrition from bacteria in their environment.

Discussion. This study showed that trilobite larvae of Limulus polyphemus are capable of overwintering, and can emerge after spending up to $8 \mathrm{mo}$ in beach sediments. We found a cohort of overwintering trilobites during 3 of the 4 years of study (Fig. 1). We infer that the larvae were emerging from the sediments during March and April of 1989 and 1991, rather than dying within the beach sediments. If the overwintering larvae had died in situ, there would have been a relative increase in the number of dead larvae in the sediments, and this was not the case (Fig. 2). Furthermore, overwintering larvae appeared to behave normally, swimming vigorously when placed in bay water, and they were competent to molt in the laboratory to the first posthatch juvenile stage.

There was no overwintering in 1989 to 1990, which may have been related to an intense storm on 21 November 1989. Sediment samples taken in the midbeach region indicated extensive disturbance, even to a depth of 15 to $20 \mathrm{~cm}$. Whereas reworking of the top $15 \mathrm{~cm}$ of sediment on these beaches is not unusual, due to wave action and burrowing by adult horseshoe crabs during the breeding season, events which disturb sediments below $15 \mathrm{~cm}$ are rare (K. Nordstrom pers. comm.). Possibly, physical disruption of the upper $15 \mathrm{~cm}$ of sediment may routinely remove any overwintering larvae from the sand; in the years in which overwintering populations of trilobite larvae did persist, they only did so at sediment depths $>15 \mathrm{~cm}$.

In retrospect, delayed emergence by larval Limulus polyphemus might well have been predicted, based on earlier laboratory observations showing that embryos and larvae have a great tolerance of environmental extremes. Lockwood (1870) observed that embryos in jars, exposed to periodic temperatures of $0^{\circ} \mathrm{C}$, remained capable of hatching for nearly $1 \mathrm{yr}$. Jegla (1982) reported that trilobite larvae can remain in good condition for at least 8 mo when stored at 13 to $15^{\circ} \mathrm{C}$. Temperature $\left(20\right.$ to $35^{\circ} \mathrm{C}$ ) and salinity $(10$ to $40 \%$ ) variations affected developmental rates but not embryo viability, and as expected, intermolt periods decreased with increasing temperature (Jegla \& Costlow 1982). Sugita (1988) discussed the physiological aspects of the broad environmental tolerances shown by horseshoe crab embryos. Thus, laboratory studies on $L$. polyphemus embryos and trilobite larvae confirm that the overwintering phenomenon which we have found is well within the physiological capabilities of the crab.

Delayed larval emergence may be a widespread phenomenon in horseshoe crabs. Following our initial presentation of this phenomenon (Loveland et al.
1989), D. Gibson (pers. comm.) found overwintering trilobites on Cape Cod (Massachusetts) beach. We have also found substantial populations of overwintering trilobites in preliminary surveys of several beaches in Raritan Bay (New Jersey). Simeone (1977) found trilobites in preserved samples taken in November, from a beach in Sandy Hook Bay (New Jersey). In the Japanese horseshoe crab Tachypleus tridentatus, overwintering by the embryonic stage preceding the trilobite has been discussed by Sekiguchi (1988). If this developmental stage (fourth embryonic molt or Stage 21 of Sekiguchi 1988) is reached in mid-summer, trilobites will hatch out in another 7 to $10 \mathrm{~d}$, but '... when the final molt occurs in September or even later, most of the embryos do not hatch out until the following spring (Sekiguchi 1988, p. 163). Although we have found a few viable Limulus polyphemus embryos during the fall months of our study, none apparently survived as embryos to the following spring in the field.

Most of the horseshoe crab eggs on Delaware Bay beaches develop into trilobites which emerge later in the same summer. Delayed emergence might be triggered by falling temperature (Jegla 1982). We have recorded sand temperatures ranging from 16.5 to $25^{\circ} \mathrm{C}$ during our September and October samples; we surmise that trilobites that do not emerge by then probably comprise the overwintering cohort. Trilobites which emerge in the late spring and summer are undoubtedly at great risk from predation by gulls and migratory shorebirds (Botton 1984b, Myers 1986, Burger \& Gochfeld 1991). In contrast, these shorebirds and gulls are essentially absent during the early spring; hence, the possibility of avian predation on the emerging overwintering trilobites is low. Overwintering does involve a major risk in that a cohort can be decimated at any time by storms. Overwintering larvae, though numerically fewer, could provide insurance in the event that previous summer cohorts had poor survivorship. At present, the relative value of summer vs overwintering cohorts to adult recruitment is unknown.

Some aquatic animals which incorporate delayed development as an obligatory phase of their life cycle have a specially modified egg or cyst stage (e.g. Wourms 1972, Bushnell \& Rao 1974, Clegg 1974, Gilbert 1974, Simpson \& Fell 1974, Coull \& Grant 1981, Grice \& Marcus 1981, Onbe 1985, Marcus 1990). In contrast, we regard overwintering by larval Limulus polyphemus as a prolonged hiatus between the trilobite and first posthatch juvenile stages. Because trilobite larvae develop within beach sediments, delayed development is not related to enhanced potential for dispersal, as is the case for planktonic larvae of some benthic invertebrates (Scheltema 1986, Pechenik 1990). The evolution of physiologically tolerant embryos and larvae, which are capable of surviving 
variable temperature and salinity regimes of intertidal beaches for months at a time, may be a factor which has contributed to the success of the horseshoe crabs over geologic time.

Acknowledgements. Dr Karl Nordstrom (Rutgers University) kindly shared some of his unpublished observations on sediment dynamics with us. We also thank Dr Dan Gibson (Worcester Polytechnic Institute) for informing us about the existence of overwintering larvae from a Cape Cod beach, and Pat Jones for field assistance. Our studies at the Shellfish Research Laboratory were made possible through the cooperation of Drs Richard Lutz and John Kraeuter, and the support of the Geraldine R. Dodge Foundation. Manuscript preparation was facilitated by a Faculty Fellowship from Fordham University to M.L.B.

\section{LITERATURE CITED}

Botton, M. L. (1984a). The importance of predation by horseshoe crabs, Limulus polyphemus, to an intertidal sand flat community. J. mar. Res. 42: 139-161

Botton, M. L. (1984b). Effects of laughing gull and shorebird predation on the intertidal fauna at Cape May, NJ. Estuar. coast. Shelf Sci. 18: 209-220

Botton, M. L., Loveland, R. E., Jacobsen, T R. (1988). Beach erosion and geochemical factors: influence on spawning success of horseshoe crabs (Limulus polyphemus) in Delaware Bay. Mar. Biol. 99: 325-332

Burger, J., Gochfeld, M. (1991). Vigilance and feeding behaviour in large feeding flocks of laughing gulls. Larus atricilla, on Delaware Bay. Estuar. coast. Shelf Sci. 32: $207-212$

Bushnell, J. H., Rao, K. S. (1974). Dormant or quiescent stages and structures among the Ectoprocta: physical and chemical factors affecting viability and germination of statoblasts. Trans. Am. microsc. Soc. 93: 524-54

Clegg, J. S. (1974). Biochemical adaptations associated with the embryonic dormancy of Artemia salina. Trans. Am. microsc. Soc. 93: 481-490

Coull, B. C., Grant, J. (1981). Encystment discovered in a marine copepod. Science 212: 342-344

French, K. A. (1979). Laboratory culture of embryonic and juvenile Limulus. In: Cohen, E. (ed.) Biomedical applications of the horseshoe crab (Limulidae). Liss, New York, p. $61-71$

Gilbert, J. J. (1974). Dormancy in rotifers. Trans. Am. microsc. Soc. 93: 490-513

Grice, G. D., Marcus, N. H. (1981). Dormant eggs of marine copepods. Oceanogr mar Biol. A. Rev. 19: 125-140

Jegla, T C. (1982). A review of the molting physiology of the trilobite larva of Limulus. In: Bonaventura, J., Bonaventura, C., Tesh, S. (eds.) Physiology and biology of horseshoe crabs: studies on normal and environmentally stressed animals. Liss, New York, p. 83-101

This note was presented by R. S. Scheltema, Woods Hole, Massachusetts, USA
Jegla, T C., Costlow, J. D. (1982). Temperature and salinity effects on developmental and early posthatch stages of Limulus. In: Bonaventura, J., Bonaventura, C., Tesh, S. (eds.) Physiology and biology of horseshoe crabs: studies on normal and environmentally stressed animals. Liss, New York, p. 103-113

Lockwood, S. (1870). The horse foot crab. Am. Nat. 4: 257-274

Loveland, R. E., Botton, M. L., Jacobsen, T. R. (1989). Seasonal aspects of organic carbon levels on sandy intertidal beaches of Delaware Bay, NJ. In: Abstracts, 10th Biennial International Estuarine Research Conference, p. 47

Marcus, N. H. (1990). Calanoid copepod, cladoceran, and rotifer eggs in sea-bottom sediments of northern Californian coastal waters: identification, occurrence and hatching. Mar. Biol 105: 413-418

Myers, J. P. (1986). Sex and gluttony on Delaware Bay. Nat. Hist. 95(5): 68-77

Onbe, T (1985). Seasonal fluctuations in the abundance of populations of marine cladocerans and their resting eggs in the Inland Sea of Japan. Mar. Biol. 87: 83-88

Pechenik, J. A. (1990). Delayed metamorphosis by larvae of benthic marine invertebrates: Does it occur? Is there a price to pay? Ophelia 32: 63-94

Rudloe, A. (1979). Locomotor and light responses of larvae of the horseshoe crab, Limulus polyphemus (L.). Biol. Bull. 157: 494-505

Scheltema, R. S. (1986). On dispersal and planktonic larvae of benthic invertebrates: an eclectic overview and summary of problems. Bull. mar. Sci. 39: 290-322

Sekiguchi, K. (1988). Embryonic development. In: Sekiguchi, K. (ed.) Biology of horseshoe crabs. Science House, Tokyo, p. $45-181$

Sekiguchi, K., Seshimo, H., Sugita, H. (1988). Post-embryonic development of the horseshoe crab. Biol. Bull. 174: $337-345$

Shuster, C. N. Jr (1982). A pictorial review of the natural history and ecology of the horseshoe crab Limulus polyphemus, with reference to other Limulidae. In: Bonaventura, J., Bonaventura, C., Tesh, S. (eds.) Physiology and biology of horseshoe crabs: studies on normal and environmentally stressed animals. Liss, New York, p. 1-52

Shuster, C. N. Jr, Botton, M. L. (1985). A contribution to the population biology of horseshoe crabs, Limulus polyphemus, in Delaware Bay. Estuaries 8: 363-372.

Simeone, C. (1977). A preliminary survey of the intertidal macrofauna of Sandy Hook Bay. Bull. N.J. Acad. Sci. 22: $6-12$

Simpson, T L., Fell, P. E. (1974). Dormancy among the Porifera: gemmule formation and germination in fresh-water and marine sponges. Trans. Am. microsc. Soc. 93: 544-577

Sugita, H. (1988). Environmental adaptation of embryos. In: Sekiguchi, K. (ed.) Biology of horseshoe crabs. Science House, Tokyo, p. 195-224

Wourms, J. P. (1972). The developmental biology of annual fishes III. Pre-embryonic and embryonic diapause of variable duration in the eggs of annual fishes. J. exp. Zool. 182: $389-414$

Manuscript first received: January 27, 1992

Revised version accepted: October 1, 1992 